\title{
The role of socio-demographic characteristics in mediating relationships between people and nature
}

\author{
$\underline{\text { Kim C. Zoeller }}^{1}$, Georgina G. Gurney ${ }^{1}, \underline{\text { Nadine Marshall }}^{2}$ and Graeme S. Cumming ${ }^{1}$
}

\begin{abstract}
Research on ecosystem services has focused primarily on questions of availability or supply and often assumes a single human community of identical beneficiaries. However, how people perceive and experience ecosystem services can differ by sociodemographic characteristics such as material wealth, gender, education, and age. Equitable environmental management depends on understanding and accommodating different perceptions of ecosystem services and benefits. We explored how socio-demographic characteristics influence people's perceptions of birds. We identified morphological and behavioral traits of birds that people care about and used these to group bird species into "cultural functional groups." Cultural functional groups of birds are defined by shared characteristics that local people perceive as contributing to cultural ecosystem services or disservices (in the same way that foraging guilds for birds can be defined by dietary information). Using perception data for 491 bird species from 401 respondents along urbanrural gradients in South Africa, we found that socio-demographic characteristics were strongly associated with human preferences for different avian cultural functional groups. Our results provide a strong quantitative demonstration that the provision of cultural ecosystem services and benefits depends on the recipient of the service and not just on the ecological community that is present.
\end{abstract}

Key Words: birds; cultural functional groups; ecosystem services; social differentiation

\section{INTRODUCTION}

Delivery of ecosystem goods and services is critical for human well-being and has become an important objective for environmental governance and management (MA 2005, BerbésBlázquez et al. 2016). Although some ecosystem goods and services are unequivocally necessary for all people, e.g., breathable air and potable water, the importance of others is more subjective and hence more likely to be controversial, e.g., fish harvesting vs. tourism on coral reefs (Lau et al. 2018). Understanding heterogeneity in how people perceive and experience elements of nature requires an understanding of the complex factors that mediate human-nature interactions, and remains a key challenge for environmental management (MA 2005, Lindemann-Matthies et al. 2014, Díaz et al. 2015, Horcea-Milcu et al. 2016, Lau et al. 2018).

Although ecosystem services research has tended to take a socially aggregated approach that focuses on an average beneficiary (Daw et al. 2011), the ways in which people perceive and interact with their environment are not uniform (Scholte et al. 2015, Gurney et al. 2017). Individuals' perceptions of ecosystems are affected by a range of socio-demographic characteristics linked to key elements of identity, such as gender, ethnicity, and education, which influence how they use, value, and access ecosystems (Lau et al. 2018, 2019). For example, Lau et al. (2019) found that individuals' ratings of cultural ecosystem services were significantly influenced by gender, with men rating the service higher than women. Furthermore, perceptions of ecosystem services can be attributed to elements of identity that are specific to individual ecosystems; for instance, degree of identification as a fisher was strongly linked to how respondents rated a range of ecosystems services from coral reef fisheries (Hicks and Cinner et al. 2014). Perceptions of ecosystem services can also be influenced by where and how people live. Urban ecosystems, for example, are perceived as more limited in their capacity to produce services than rural ecosystems (Lapointe et al. 2019). As a result, the ability of people to access ecosystem services may be more restricted in urban areas. Given the rapid rates of urbanization in the Global South generally, and in Africa in particular, understanding how perceptions of ecosystem services change along an urban-rural gradient is important in ensuring the equitable management of ecosystems in developing countries (Elmqvist et al. 2013).

Taking a socially disaggregated approach to perceptions of ecosystem services can clarify who experiences costs and benefits related to ecosystem change and management, and thus help ensure equitable outcomes from decision-making processes. Aggregated assessments of ecosystem services that ignore differences between people may obscure the preferences and interests of subgroups, potentially resulting in management decisions that lead to unequal access to ecosystem services within society. Differential access to ecosystem services has been highlighted as a major gap in ecosystem service research, particularly in areas where systemic inequalities, exclusion, and segregation may result in conflict and violence (Lapointe et al. 2019). Examining heterogeneity in perceptions of ecosystem services is particularly important in post-colonial countries because colonization typically led to unequal access to ecosystem services, mirroring broader social and economic inequalities (Musavengane and Leonard 2019). Sustained unequal access to ecosystem services risks reinforcing existing social and economic inequalities (Daw et al. 2011, Sikor 2013). In South Africa, for example, formalized segregation based on "race" under apartheid has led to access to ecosystem services historically being unevenly distributed, with management decisions largely informed by white and "upper class" priorities (Musavengane and Leonard 2019). Despite progress in economic and social integration since the end of apartheid in 1994, South African society remains economically and socially divided along racial lines (Ramutsindela 2007, Kepe

\footnotetext{
${ }^{1}$ Australian Research Council Centre of Excellence for Coral Reef Studies, James Cook University, Townsville, Queensland, Australia,

${ }^{2}$ Commonwealth Scientific and Industrial Research Organisation Land and Water, James Cook University, Townsville, Queensland, Australia
} 
2009; F. Amodio and G. Chiovelli 2014, unpublished manuscript). Therefore, to foster equitable and inclusive environmental management and governance in this context, it is critical to consider the legacy of apartheid by examining how human-nature relationships are related to race (Kepe 2009, Martin et al. 2016).

Although the interactions between people and nature that produce cultural ecosystem services are mediated by identity and values, most studies of cultural ecosystem services overlook the socio-cultural factors that produce preferences (Plieninger et al. 2013, Zoderer et al. 2016). In this paper, we addressed this gap by asking how socio-demographic characteristics relate to people's perceptions of cultural ecosystem services provided by birds in South Africa. We used a functional group approach, grouping birds that shared similar behavioral and morphological traits that are relevant to cultural service provision. Functional approaches have a long history in avian ecology but are more typically applied to foraging guilds, e.g., insectivores, frugivores, raptors (Sekercioglu 2002). The functional group approach reduces irrelevant between-species heterogeneity and facilitates the identification of general patterns (Kahmen et al. 2002, de Arruda Almeida et al. 2018). It is particularly useful in establishing linkages between the functional traits of individual organisms and the production of ecosystem services (Sekercioglu 2002). Individual functional traits of organisms that underpin provisioning and regulating ecosystem services have been widely reported (Sekercioglu 2002, Cumming and Child 2009), but the functional traits that underpin cultural ecosystem services have received limited attention. Because cultural ecosystem services are inherently intangible (Chan et al. 2012), developing a functional classification for cultural ecosystem services relies on capturing human perception. Previous research (Zoeller et al. 2020) identified six cultural functional groups of birds. These were defined by species-level characteristics that people perceive as contributing to cultural ecosystem services or disservices (Zoeller et al. 2020). By comparing the demographic characteristics of respondents to their preferences for different avian functional groups, we were able to explore the influence of socio-cultural factors on cultural service provision.

\section{MATERIALS AND METHODS}

\section{Background and study sites}

From 1948 to 1994 , South Africa was governed by a policy of apartheid, characterized by legislation that institutionalized segregation of "races" (Butler 2003). This legislation was partly enforced through physical separation of races, particularly through the Group Areas Act of 1950-1991 (which enforced racial segregation in cities), and the creation of homelands through the Promotion of Bantu Self-Government Act (1959-1994). This Act removed African people from urban and "white" areas into designated "Bantustans" based on racial and linguistic markers (Chisholm 2012). Racial segregation during apartheid resulted in the reinforcement of cultural identities along racial lines (Nengwekhulu 1986). The resulting economic and social impacts included disparate wealth distribution along an urban-rural gradient, as well as independent cultural development (F. Amodio and G. Chiovelli 2014, unpublished manuscript). Despite progress in economic and cultural integration since the end of apartheid, South African society remains economically and socially divided (Ramutsindela 2007; F. Amodio and G. Chiovelli 2014, unpublished manuscript). The South African census recognizes 11 official languages but still asks people to self-identify as belonging to one of four racial groups: black $(80.6 \%)$, coloured (i.e., person of mixed ancestry; $8.7 \%)$, Indian/Asian $(2.5 \%)$, and white $(8.1 \%$; Statistics South Africa 2011).

\section{Respondent selection}

We conducted semi-structured interviews with 401 respondents from 2016 to 2017 in five provinces in South Africa: Western Cape, Northern Cape, Eastern Cape, Mpumalanga, and Limpopo (Fig. 1). These areas contain six of the country's nine biomes: Albany thicket, forest, fynbos, grassland, savanna, and Succulent Karroo. This diversity in vegetation supports South Africa's rich birdlife, with 856 species recorded, 68 of which are endemic (Taylor and Peacock 2018). Study sites in the selected provinces were stratified to fulfil criteria of encompassing both urban and rural environments, being safe, feasible, and efficient to access, and comprising diverse socio-demographic groups (Zoeller et. al. 2020). Although time and budget constraints concentrated interviews in the Western Cape, South Africa's demographic variability was well-represented in the sample (Statistics South Africa 2011, Zoeller et al. 2020). Our dataset included individuals who occupied a range of locations along an urban-rural gradient, specifically city centers ( $n=26$ individuals), just outside the city $(n=16)$, city suburbs $(n=44)$, farms $(n=80)$, nature reserves $(n$ $=19)$, rural areas $(n=92)$, towns $(n=101)$, just outside towns $(n$ $=7)$, and townships $(n=16)$. Urban locations consisted of cities (including suburbs), towns, and townships. A town was classified as a developed area smaller than a city, with access to amenities, infrastructure, and municipal services. Townships were classified as urban because they occurred within greater city limits with limited access to natural habitats.

Fig. 1. Site map of respondent locations across South Africa.

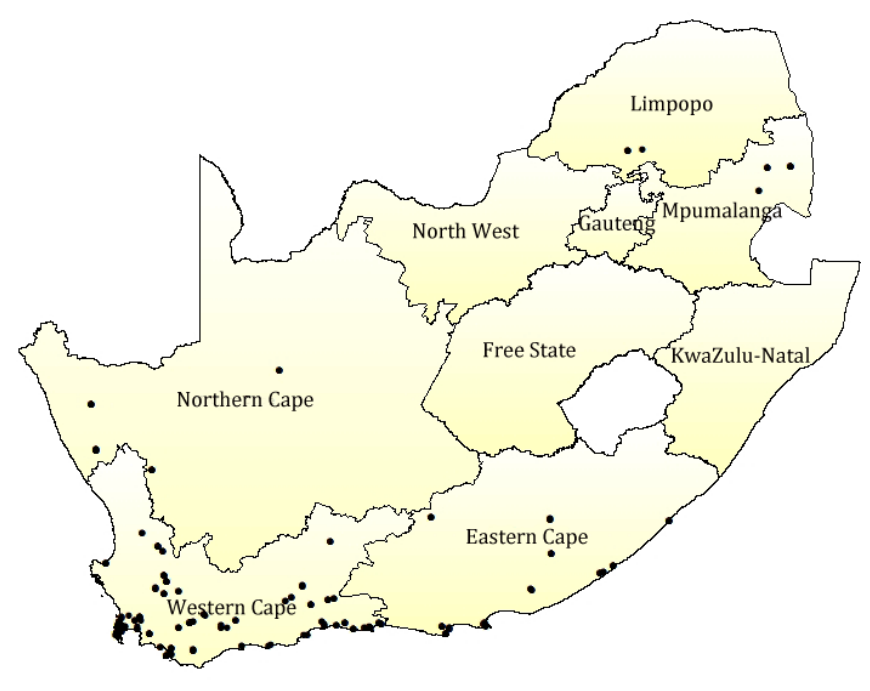

A mixture of purposive and convenience sampling was used to select respondents and to ensure variation in socio-demographic characteristics (Etikan et al. 2016). Respondents were recruited via the Birdlife South Africa network, as well as opportunistically in public spaces, e.g., parks, libraries, and community meetings, in each location. Given the variety of people this approach 
encompassed, our dataset included responses from inter alia the general public, land managers, farm managers and laborers, conservationists, students, and tour guides.

\section{Bird traits}

To determine their individual perceptions of birds, respondents were asked to rate their perceptions of a random selection of 30 bird species as positive, negative, or neutral (Zoeller et al. 2020). The perception of species was based on experiential knowledge, with each respondent being shown a photograph of the rated bird species. This was especially useful when interviewing non-birders, who might have seen the species in their local environment but not have been familiar with the species name. We randomly selected a subset of 30 bird species for each interview and cross referenced the bird species with the respondent's location. If the locations did not match, the species was discarded for that interview. This was repeated until bird and respondent location coincided for 30 species. After each of the 30 species had been rated, respondents were asked to justify the ratings of the birds based on the traits respondents perceived in that species. This part of the interview process was unstructured, and there were no limits to the justifications respondents could cite to ensure that we captured the full range of traits perceived by respondents. An example of a response is as follows: "Verreaux's Eagle-Owl receives a rating of 1 because it is associated with witchcraft. I don't like the bird's song because it reminds me of danger, and I don't like seeing the bird because it brings bad luck." This process was repeated for each of the 30 bird species per respondent, with the length of interviews ranging between one to two hours. The individual bird species' ratings were not used in this analysis.

\section{Cultural functional group classification}

Based on the explanations underlying the bird scores, we identified 45 perceived traits across the 401 interviews with respondents (see Appendix 1 for description of traits). For example, from the respondent's description of the Verreaux's Eagle-Owl above, we identified negative symbology and negative song as the dominant traits perceived by that respondent. These traits were scored as either present (1) or absent (0).

To identify cultural functional groups, we conducted a K-means cluster analysis on the 45 traits identified during the interview process. The K-means cluster analysis allocated each trait into six clusters, with the number of clusters being determined based on its silhouette coefficient. The traits enabled us to identify the dominant attributes of each cluster, which were used to develop a typology of cultural functional groups. The cultural functional groups and their derivation are described in Zoeller et al. (2020), and are identified as Visual Traits; Negative Visual and Behavioral Traits; Movement and Ecological Traits; Place Association and Abundance Indicators; Common Traits; and Behavioral Traits.

\section{Socio-demographic characteristics}

Relevant socio-demographic characteristics were obtained from each respondent during the interview process, enabling us to relate perceptions of bird traits to the socio-demographic characteristics of individual respondents. Respondents' socio-demographic characteristics are summarized in Appendix 1. From previous studies we identified the following socio-demographic characteristics as potentially important in influencing perceptions of cultural functional groups in the context of South Africa: education, gender, language, race, residential location, coarse residential location, and birding self-classification. The potential importance of these characteristics as influences on perceptions of cultural functional groups is outlined in Table 1. We included biogeographical variables to control for external factors that may influence people's perceptions of cultural functional groups. These variables included biome and province, since local vegetation influences the distribution of bird communities (Belaire et al. 2015). We additionally included frequency of bird encounters (ranging from daily to yearly) as a control variable because greater frequencies of interactions with birds may create a feedback loop in which more sightings of bird species increases the ability of individuals to perceive their cultural functions (Clergeau et al. 1998, Gaston et al. 2018).

\section{Data analysis}

Data from each respondent included (1) socio-demographic characteristics; (2) bird ratings; and (3) score justifications. Traits elicited from the score justification process were grouped using $\mathrm{K}$-means cluster analysis (a distance-based measurements of similarity), producing six distinct cultural functional groups composed of different birds (see Appendices 2 and 3). Given that the traits that define the six cultural functional groups are based on perceptions, they are associated with a suite of sociodemographic characteristics, representative of individual respondents who cited that specific trait during the interview process. Thus, we examined how socio-demographic characteristics are related to cultural functional groups, i.e., perceptions of bird traits.

To determine whether socio-cultural characteristics were associated with cultural functional groups based on perceived bird traits, we first used $\chi^{2}$ analyses to compare differences in the observed frequencies of socio-demographic characteristics between avian cultural functional groups. These analyses clarified the potential relevance of individual socio-demographic (explanatory) variables but were not able to provide estimates of the influence of a particular variable while controlling for the effects of the other explanatory variables.

We then used multinomial logistic regression (Upton 2017) to explore the relative influences of socio-demographic characteristics on perceptions of cultural functional group in a way that incorporated the interactions between explanatory variables. Multinomial regression can be seen as an extension of logistic regression, i.e., with a response variable of 1 or 0 , to consider more than two categories. We used multinomial analysis to determine the probability of respondents perceiving each of six cultural functional groups based on socio-demographic characteristics, i.e., we treated the socio-demographic variables as explanatory or $\mathrm{X}$ variables and the six cultural functional groups as a single categorical response or $\mathrm{Y}$ variable with six categories. The traditional assumptions of regression analysis need not be met to run a multinomial logistic regression, although it is important that observations are independent (Corona et al. 2008). In our model, cultural functional groups were treated as the dependent variables and each of the socio-demographic variables was treated as independent. We also included three variables representing biome, province, and frequency of bird encounter as independent variables in order to control for key biogeographical factors thought to influence ecosystem service perceptions. We designated Movement and Ecological traits as the reference 
Table 1. Socio-demographic characteristics of respondents, how they were measured, and how these characteristics might influence perception of ecosystem services, with examples.

\begin{tabular}{|c|c|c|c|}
\hline $\begin{array}{l}\text { Socio-demographic } \\
\text { characteristic }\end{array}$ & Measurement & Category & Mechanism and examples \\
\hline Age & Years & Continuous & $\begin{array}{l}\text { Age has been shown to be related to perceptions of ecosystem services } \\
\text { (Daw et al. 2011), with related priorities, responsibility, and entitlements } \\
\text { shifting with age (Lau et al. 2019, Lapointe et al. 2020). For example, Lau } \\
\text { et al. (2019) found that older respondents assigned higher ratings to } \\
\text { fuelwood than younger respondents in Papua New Guinea. }\end{array}$ \\
\hline
\end{tabular}

\begin{tabular}{|c|c|c|c|}
\hline $\begin{array}{l}\text { Birding self- } \\
\text { classification }\end{array}$ & Interest level & $\begin{array}{l}\text { Non-birder } \\
\text { Casual birder } \\
\text { Enthusiastic birder } \\
\text { Fanatical birder }\end{array}$ & $\begin{array}{l}\text { Elements of identity directly related to the service at hand have been shown } \\
\text { to influence perceptions of ecosystem services. For example, Hicks and } \\
\text { Cinner (2014) found that the fishery benefits people perceived from coral } \\
\text { reefs were directly related to their strength of identity as a fisher. }\end{array}$ \\
\hline Race & $\begin{array}{l}\text { Self-classified } \\
\text { racial identity }\end{array}$ & $\begin{array}{l}\text { Black } \\
\text { Coloured } \\
\text { White }\end{array}$ & $\begin{array}{l}\text { In a South African context, race and language are key markers of a person's } \\
\text { identity (Ramutsindela 2007). Because ecosystem services are co- } \\
\text { constructed (Fischer and Eastwood 2016), knowledge, experience, and } \\
\text { preferences for ecosystem services are likely to be influenced by race and } \\
\text { language. }\end{array}$ \\
\hline Languages & $\begin{array}{l}\text { Self-identified home } \\
\text { language }\end{array}$ & $\begin{array}{l}\text { Afrikaans } \\
\text { English } \\
\text { Xhosa } \\
\text { Other African languages }\end{array}$ & \\
\hline Gender & Self-identified gender & $\begin{array}{l}\text { Male } \\
\text { Female }\end{array}$ & $\begin{array}{l}\text { Normative gender roles have been shown to influence access to ecosystem } \\
\text { services and the way these services are perceived (Lau et al. 2019, Yang et } \\
\text { al. 2019). For example, Yang et al. (2019) suggested that women generally } \\
\text { express stronger connections to cultural ecosystem services and have a } \\
\text { greater awareness of the spiritual benefits of ecosystem services. }\end{array}$ \\
\hline $\begin{array}{l}\text { Years of formal } \\
\text { education }\end{array}$ & $\begin{array}{l}\text { Years of school } \\
\text { completed }\end{array}$ & $\begin{array}{l}<\text { Grade } 10 \\
\text { Grade } 10 \text { to Grade } 12 \\
\text { Diploma } \\
\text { Degree } \\
\text { Honours graduate } \\
\text { Master's graduates } \\
\text { PhD graduates }\end{array}$ & $\begin{array}{l}\text { Perceptions of ecosystem services have been shown to be influenced by level } \\
\text { of formal education as knowledge on ecological systems shift (Lau et al. } \\
2019 \text {, Echeverri et al. 2020). For example, Hicks and Cinner (2014) found } \\
\text { that years of education influenced how respondents perceived material } \\
\text { benefits associated with ecosystem services in Madagascar and Tanzania. }\end{array}$ \\
\hline Residential Location & $\begin{array}{l}\text { Self-identified } \\
\text { residential classification }\end{array}$ & $\begin{array}{l}\text { City center } \\
\text { Just outside city } \\
\text { City suburbs } \\
\text { Town } \\
\text { Just outside town } \\
\text { Township } \\
\text { Farm } \\
\text { Nature Reserve } \\
\text { Rural }\end{array}$ & $\begin{array}{l}\text { Bird diversity decreases with urbanization, suggesting that an individual's } \\
\text { position along an urbanization gradient, both at the residential level and } \\
\text { coarse level (simple urban vs. rural contrasts), is likely to affect biodiversity- } \\
\text { based perception of ecosystem services (Clergeau et al. 1998). }\end{array}$ \\
\hline Coarse Location & $\begin{array}{l}\text { Broad classification } \\
\text { based on population, } \\
\text { infrastructure, and } \\
\text { access to nature }\end{array}$ & $\begin{array}{l}\text { Rural } \\
\text { Urban }\end{array}$ & \\
\hline
\end{tabular}

category for this model because this analysis produced the lowest AIC. One category for each independent variable was used as a reference category, with the model predicting the probability of respondents perceiving each functional group against the sociodemographic reference category (Koster and McElreath 2017). All analyses were conducted in R (version 3.1.3) using stats package v7.3-14 and nnet package v7.3-14.

To reduce the dimensionality of our data, we screened for redundancy by separately coding each independent variable as a set of individual categories and removing non-significant categories from the multinomial model. We reran the analysis three times, removing non-significant variables each time, to identify the model that best fit our data based on the lowest AIC value. As summarized in Table 2, the model with the lowest AIC included variables in the broader categories of age, gender, home language, education, and race. All categories were z-score standardized. 
Table 2. Regression coefficients (CF), standard error (SE), z-statistic, and p-value of the multinomial model between dimensions of socio-demographic characteristics and cultural functional groups. Socio-demographic characteristics missing $p$-values indicate nonsignificance $(\mathrm{p}>0.05)$.

\begin{tabular}{|c|c|c|c|c|c|c|c|c|c|c|c|c|c|c|c|c|c|c|c|c|c|}
\hline \multirow[t]{2}{*}{$\begin{array}{l}\text { Charact- } \\
\text { eristics }\end{array}$} & \multirow[t]{2}{*}{ Category } & \multicolumn{4}{|c|}{ Behavioral Traits } & \multicolumn{4}{|c|}{ Common Traits } & \multicolumn{4}{|c|}{$\begin{array}{c}\text { Negative Visual and Negative } \\
\text { Behavioral Traits }\end{array}$} & \multicolumn{4}{|c|}{$\begin{array}{l}\text { Place Association and } \\
\text { Abundance Indicators }\end{array}$} & \multicolumn{4}{|c|}{ Visual Traits } \\
\hline & & $\mathrm{CF}$ & SE & $\begin{array}{c}\mathrm{z} \\
\text { statistic }\end{array}$ & $\begin{array}{c}\text { P- } \\
\text { value }\end{array}$ & $\mathrm{CF}$ & SE & $\begin{array}{c}\mathrm{z} \\
\text { statistic }\end{array}$ & $\begin{array}{c}\text { P- } \\
\text { value }\end{array}$ & $\mathrm{CF}$ & SE & $\begin{array}{c}\mathrm{z} \\
\text { statistic }\end{array}$ & $\begin{array}{c}\text { P- } \\
\text { value }\end{array}$ & $\mathrm{CF}$ & $\mathrm{SE}$ & $\begin{array}{c}\mathrm{z} \\
\text { statistic }\end{array}$ & $\begin{array}{c}\text { P- } \\
\text { value }\end{array}$ & $\mathrm{CF}$ & SE & $\begin{array}{c}\mathrm{z} \\
\text { statistic }\end{array}$ & P-value \\
\hline & (Intercept) & -1.66 & 0.52 & -3.19 & 0.01 & -3.54 & 0.77 & -4.56 & 0.001 & -0.29 & 0.33 & -0.88 & & -2.30 & 0.48 & -4.77 & 0.001 & -3.26 & 0.53 & -6.14 & 0.001 \\
\hline Age & Continuous & -0.013 & 0.0029 & -4.61 & 0.001 & -0.0017 & 0.0032 & -0.52 & & -0.0027 & 0.0019 & -1.40 & & 0.0054 & 0.0025 & 2.18 & 0.05 & 0.014 & 0.0022 & 6.34 & 0.001 \\
\hline Gender & Male & 0.41 & 0.08 & 5.47 & 0.001 & 0.41 & 0.09 & 4.55 & 0.001 & 0.21 & 0.05 & 4.07 & 0.001 & 0.69 & 0.07 & 9.99 & 0.001 & 0.35 & 0.06 & 5.82 & 0.001 \\
\hline Home & English & 0.09 & 0.12 & 0.72 & & 0.16 & 0.15 & 1.07 & & 0.05 & 0.09 & 0.53 & & 0.04 & 0.12 & 0.35 & & 0.05 & 0.11 & 0.46 & \\
\hline language & $\begin{array}{l}\text { Other } \\
\text { African } \\
\text { languages }\end{array}$ & 0.17 & 0.33 & 0.52 & & 0.93 & 0.63 & 1.46 & & -0.20 & 0.21 & -0.92 & & 0.16 & 0.33 & 0.48 & & 0.99 & 0.40 & 2.45 & 0.05 \\
\hline \multirow{7}{*}{ Education } & Xhosa & 0.08 & 0.33 & 0.23 & & 1.32 & 0.62 & 2.11 & 0.05 & -0.13 & 0.21 & -0.65 & & 0.15 & 0.32 & 0.46 & & 1.38 & 0.40 & 3.46 & 0.001 \\
\hline & $<$ Grade 10 & -0.92 & 0.30 & -3.10 & 0.01 & -1.19 & 0.32 & -3.67 & 0.001 & -0.63 & 0.21 & -2.96 & 0.01 & -0.45 & 0.28 & -1.65 & & -0.65 & 0.24 & -2.71 & 0.01 \\
\hline & $\begin{array}{l}\text { Grade } 10 \text { - } \\
\text { Grade } 12\end{array}$ & -0.79 & 0.27 & -2.90 & 0.01 & -1.05 & 0.30 & -3.55 & 0.001 & -0.47 & 0.20 & -2.34 & 0.05 & -0.56 & 0.26 & -2.13 & 0.05 & -0.83 & 0.23 & -3.64 & 0.001 \\
\hline & Degree & -0.57 & 0.30 & -1.92 & & -1.07 & 0.33 & -3.25 & 0.05 & -0.27 & 0.22 & -1.24 & & -0.48 & 0.29 & -1.68 & & -0.70 & 0.25 & -2.81 & 0.01 \\
\hline & Diploma & -0.69 & 0.29 & -2.39 & 0.05 & -0.94 & 0.32 & -2.96 & 0.05 & -0.22 & 0.21 & -1.03 & & -0.15 & 0.27 & -0.54 & & -0.69 & 0.24 & -2.86 & 0.01 \\
\hline & Honours & -0.68 & 0.33 & -2.05 & 0.05 & -0.43 & 0.35 & -1.23 & & -0.06 & 0.24 & -0.27 & & -0.10 & 0.31 & -0.33 & & -0.48 & 0.28 & -1.70 & \\
\hline & Masters & -0.62 & 0.33 & -1.91 & & -0.36 & 0.35 & -1.04 & & -0.66 & 0.25 & -2.67 & 0.01 & -0.46 & 0.31 & -1.45 & & -0.11 & 0.27 & -0.42 & \\
\hline \multirow{3}{*}{ Race } & $\mathrm{PhD}$ & 0.18 & 0.35 & 0.52 & & -0.30 & 0.39 & -0.77 & & 0.09 & 0.27 & 0.35 & & -0.17 & 0.36 & -0.48 & & -0.01 & 0.30 & -0.02 & \\
\hline & Coloured & -0.04 & 0.32 & -0.13 & & 1.51 & 0.62 & 2.45 & 0.05 & -0.34 & 0.20 & -1.66 & & 0.26 & 0.32 & 0.83 & & 1.19 & 0.39 & 3.03 & 0.01 \\
\hline & White & 0.60 & 0.30 & 2.02 & 0.05 & 1.84 & 0.60 & 3.06 & 0.01 & 0.07 & 0.18 & 0.40 & & 0.51 & 0.30 & 1.73 & & 1.19 & 0.38 & 3.14 & 0.01 \\
\hline
\end{tabular}

\section{RESULTS}

Results from $\chi 2$ tests suggested that socio-demographic factors were significantly associated with people's preferences for different avian cultural functional groups. Comparisons of human preferences across avian functional groups differed significantly on all of the dimensions of socio-demographic characteristics that were measured: age $\left(\chi^{2} 5441.2\right.$, df $=20$, pvalue $<0.001)$, gender $\left(\chi^{2}=147.7, \mathrm{df}=5\right.$, p-value $\left.<0.001\right)$, race $\left(\chi^{2}=150.3, \mathrm{df}=30, \mathrm{p}\right.$-value $\left.<0.001\right)$, language $\left(\chi^{2}=108.4, \mathrm{df}=\right.$ 15 , p-value $<0.05)$, education $\left(\chi^{2}=230.9, \mathrm{df}=6, \mathrm{p}\right.$-value $\left.<0.001\right)$, coarse location $\left(\chi^{2}=29.6, \mathrm{df}=5\right.$, $\mathrm{p}$-value $\left.<0.001\right)$, residential location $\left(\chi^{2}=208.4\right.$, df $=40$, p-value $\left.<0.001\right)$, and birding selfclassification $\left(\chi^{2}=88.8, \mathrm{df}=15, \mathrm{p}\right.$-value $\left.<0.001\right)$. A higher percentage of respondents across all socio-demographic characteristics reported perceiving Visual Traits than any other cultural functional group (Fig. 2). In contrast, Common Traits and Behavioral Traits consistently had the lowest number of respondents, suggesting that individual people are more likely to perceive avian visual cues than traits pertaining to behavior or observation frequency. (Fig. 2).

The multinomial analysis supported the argument that sociodemographic characteristics are associated with perceptions of birds from all six cultural functional groups (Figs. 2 and 3, Table $2)$. Age, gender, race, language, and education emerged as important socio-cultural characteristics influencing what people perceived about birds. The model explained $24 \%$ of the variance $(\mathrm{AIC}=37118.65$, residual variance $=36818.65$, McFadden pseudo $\mathrm{R}^{2}=0.24, \mathrm{p}<0.05$; Table 2). Socio-demographic characteristics differed across cultural functional groups, both in the significance of the effect and whether it was negative or positive (Figs. 2 and 3, Table 2). Gender and education were consistently significant as explanatory variables across all avian cultural functional groups, suggesting these characteristics are strongly associated with human perceptions of birds. Home language was significant for Visual Traits, and race was significant for Behavioral Traits and Visual Traits, suggesting that perceptions of birds differ significantly for people of different races and languages. Once we reduced the dimensionality of our data, only one province was significant for Behavioral Traits (Western Cape) and three biomes for Place Association and Abundance Indicators and Visual Traits (forest and fynbos, fynbos, and Succulent Karoo).

Gender was the only socio-demographic characteristic that significantly explained differences in what people perceived across all avian cultural functional groups. Men were more likely than women to perceive Behavioral Traits, Common Traits, Negative Visual and Behavioral Traits, Place Association and Abundance Indicators, and Visual Traits, compared with the Movement and Ecological Traits Group. Increasing age was significantly positively related to perceiving the Place Association and Visual Traits functional groups (compared to the Movement and Ecological Traits group), and negatively related to the Behavioral Traits, Common Traits, and Negative Visual and Behavioral Traits functional groups (although the relationship was not significant with regards the latter two). There were few significant relationships for home language, except that Xhosa speakers were significantly more likely than Afrikaans speakers to perceive bird species in the Common Traits and Visual Traits functional groups than in the Movement and Ecological Traits group. For race, there was only one significant difference between those who identified as coloured as opposed to black, whilst there were three significant differences between white and black respondents. Respondents identifying as white were significantly more likely than black respondents to perceive traits associated with the Behavioral Traits, Commons Traits, and Visual Traits functional groups as opposed to the Movement and Ecological Traits functional group.

\section{DISCUSSION}

The results indicate that all socio-demographic characteristics were significantly related to perceptions of cultural functional groups, and hence with perceptions of bird traits and ultimately the receipt of cultural ecosystem services and benefits. Perceptions of avian cultural functional groups were not uniform across the range of socio-demographic characteristics that were measured, 
Fig. 2. Percentage distribution of socio-demographic characteristics between dimensions of cultural functional groups: (a) race, (b) language, (c) gender, (d) birding selfclassification, (e) education, and (f) age.

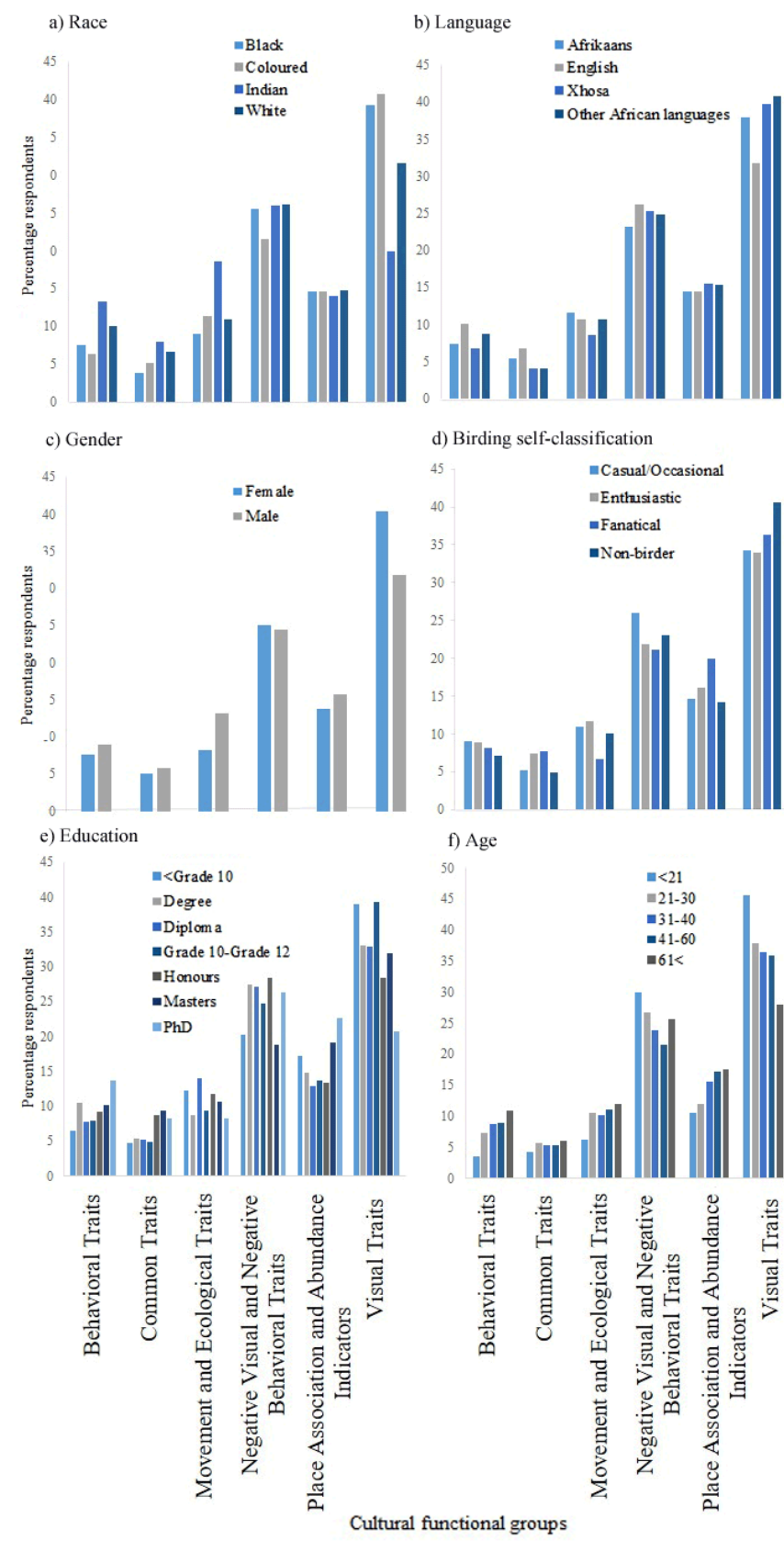

highlighting the importance of disaggregating the beneficiaries of ecosystem services. The association of age, gender, race, language, and education with different avian cultural functional groups emerged as particularly significant, suggesting that these characteristics can be used to predict patterns in perceptions of cultural ecosystem services.
Fig. 3. Percentage distribution of socio-demographic characteristics between dimensions of cultural functional groups: (a) residential location and (b) coarse location.

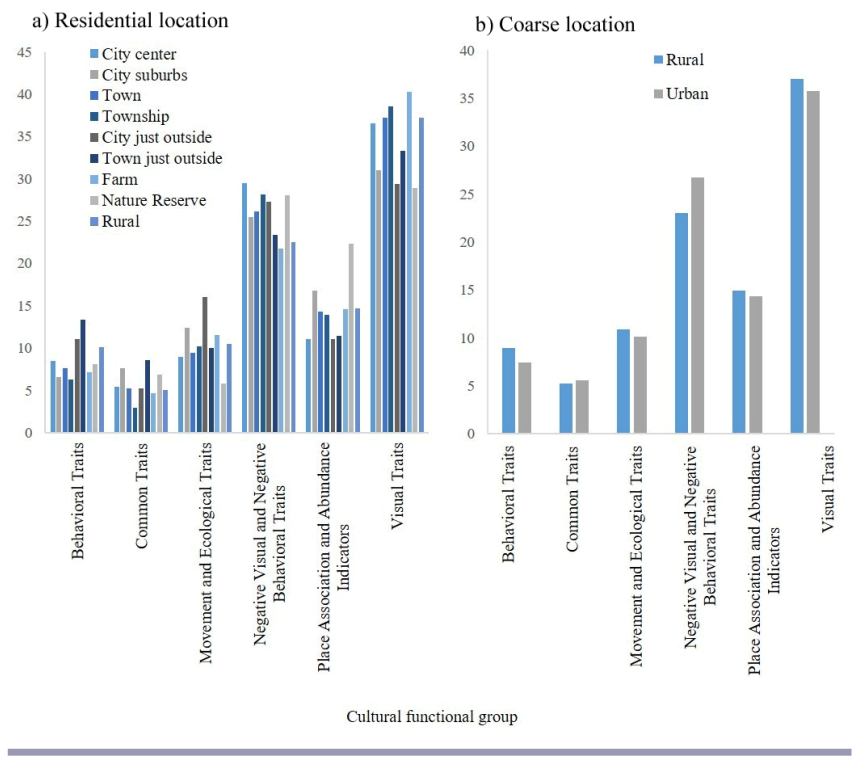

Heterogeneity in the ways people perceive birds may be indicative of individuals' differential abilities to access ecosystem services, where access is constructed through identification with particular socio-demographic characteristics (following Hicks and Cinner 2014). For example, language as an influence on perceptions of bird traits was significantly associated with Xhosa and other African language-speaking respondents. Contrasts between perceptions of birds according to racial and linguistic characteristics probably relate to forced segregation during apartheid, where black and coloured South Africans were relocated to rural areas (Butler 2003, Musavengane and Leonard 2019). In a South African context, identification with a specific race and social construction through a specific language are likely to mediate an individual's interaction with their environment and contribute to their ability to access ecosystem services (Kittinger et al. 2012, Hicks and Cinner 2014, Musavengane and Leonard 2019). Understanding the extent to which language and race inform socio-cultural values is of particular interest when cultural heritage, norms, practices, and traditions have developed in forced isolation (Butler 2003, Kittinger et al. 2012, Tengberg et al. 2012). Significant differences among respondents based on racial and linguistic characteristics can help determine how ecosystem service benefits differ according to social subgroups and is important in promoting equitable access to ecosystem services (Lau et al. 2018)

Our results suggest that urbanization did not affect perceptions of cultural functional groups. Despite there being significant differences between respondents living in different locations in the Chi-square tests, residential and coarse location were not significantly associated with particular avian cultural functional groups in the presence of other socio-demographic variables in the multinomial regression. Because research has indicated that bird diversity decreases with urbanization (Suri et al. 2017), it was 
expected that an individual person's position along an urbanization gradient would affect their perception of ecosystem services (Clergeau et al. 1998), particularly because others have found that species traits may be filtered in urban environments (Croci et al. 2008). Indeed, urban dwellers more frequently report limitations to ecosystem services benefits than rural dwellers (Lapointe et al. 2019), where increased levels of land use intensity reduce the flow of ecosystem services (Balzan et al. 2018). However, the relationships between how people interact with their environment and where they live are still connected in potentially important ways in South Africa. Because of forced segregation based on race for most of South Africa's colonial history, many urban households of historically disenfranchised communities in South Africa still maintain strong links to their traditional rural homes (Smit 1998, Hamann et al. 2016). Rural-urban linkages are reinforced by circular migration and migrant labor between rural and urban households (Smit 1998). This may explain why perceptions of cultural functional groups still appear to be more strongly linked within shared social constructs that span urban and rural communities in South Africa. Understanding how perceptions of cultural functional groups are distributed across space is important in developing sustainable land management strategies and can be used to identify linkages between cultural ecosystem hotspots and local socio-cultural identities (Plieninger et al. 2013).

Establishing where differences occur between people in their perceptions of avian cultural functional groups facilitates identification of potential barriers to ecosystem service access (Mensah et al. 2017). In countries where unequal access to resources has previously been institutionalized, understanding the underlying drivers of differential perceptions of ecosystem service is important in promoting distributive justice with respect to ecosystem services across previously disenfranchised communities (Musavengane and Leonard 2019). Indeed, in other contexts, research shows that ecosystem degradation and ecosystem service loss disproportionally affect marginalized groups, such as the poor, women, and indigenous communities (Sievers-Glotzbach 2013). However, the challenges associated with capturing the complex socio-demographic factors that constrain access to ecosystem services (and subsequently result in diverse ecosystem service perceptions) have resulted in limited inclusion of diverse stakeholder preferences in ecosystem management (Kittinger et al. 2012, Iniesta-Arandia et al. 2014, Gurney et al. 2015). Incorporating diverse perceptions in ecosystem service management is particularly important in areas with social inequality, as the linkages between conservation, human well-being, and the socio-demography of ecosystem users are often not explicitly discussed in the equitable management discourse (Kepe 2009, Musavengane and Leonard 2019). Management initiatives that seek to maintain ecosystem service delivery must therefore tailor their approach to match locally specific preferences. This requires heterogeneity in ecosystem service perceptions to be incorporated into environmental management decisions (Lau et al. 2018) because we have shown here that focusing only on specific cultural functional groups risks discounting the preferences of local ecosystem users.

\section{CONCLUSION}

We have shown that exploring the drivers of perceptions of avian cultural functional groups, defined by the traits that people care about in birds, can promote an understanding of the causes of heterogeneity in people's relationships with their environment. Differences in perceptions of cultural functional groups were significant across all socio-demographic characteristics, implying that socio-demographic characteristics inform how people experience bird-related ecosystem services and their benefits. Notably, age, gender, race, language, and education were shown to significantly affect perceptions of cultural services from birds. Further research on how different societal groups perceive and experience ecosystem services will be critical for resolving inequities in the distribution of ecosystem service benefits across socially heterogeneous communities (Kepe 2009, SieversGlotzbach 2013) and ensuring just and equitable management of ecosystems.

Responses to this article can be read online at: https://www.ecologyandsociety.org/issues/responses. php/12664

\section{Acknowledgments:}

We thank the numerous respondents who participated in interviews and enthusiastically volunteered their time and personal insight. We would also like to extend our gratitude to Dominic Henry and Kristine Maciejewski who provided early support and feedback on the sampling protocol. This research was funded by the National Research Foundation (NRF) through a Blue Skies grant to GSC, by the DSTINRF Centre of Excellence at the Percy FitzPatrick Institute, and by James Cook University.

\section{Data Availability:}

The datalcode that support the findings of this study are available on request from the corresponding author, KCZ. None of the datal code are publicly available because research participants were ensured their anonymity in this study, and we are hesitant to include information that could compromise the privacy of research participants. Ethical approval for this research study was granted by the University of Cape Town (SFREC 48_2012)

\section{LITERATURE CITED}

Balzan, M. V., J. Caruana, and A. Zammit. 2018. Assessing the capacity and flow of ecosystem services in multifunctional landscapes: evidence of a rural-urban gradient in a Mediterranean small island state. Land Use Policy 75:711-725. https://doi.org/10.1016/j.landusepol.2017.08.025

Belaire, J. A., L. M. Westphal, C. J. Whelan, and E. S. Minor. 2015. Urban residents' perceptions of birds in the neighborhood: biodiversity, cultural ecosystem services, and disservices. Condor 117:192-202. https://doi.org/10.1650/CONDOR-14-128.1

Berbés-Blázquez, M., J. A. González, and U. Pascual. 2016. Towards an ecosystem services approach that addresses social power relations. Current Opinion in Environmental Sustainability 19:134-143. https://doi.org/10.1016/j.cosust.2016.02.003 
Butler, A. 2003. South Africa's political futures. Government and Opposition 38:93-112. https://doi.org/10.1111/1477-7053.t01-1-00006

Chan, K. M. A., T. Satterfield, and J. Goldstein. 2012. Rethinking ecosystem services to better address and navigate cultural values. Ecological Economics 74:8-18. https://doi.org/10.1016/j. ecolecon.2011.11.011

Chisholm, L. 2012. Apartheid education legacies and new directions in post-apartheid South Africa. Storia delle Donne 8:81-103.

Clergeau, P., J.-P. L. Savard, G. Mennechez, and G. Falardeau. 1998. Bird abundance and diversity along an urban-rural gradient: a comparative study between two cities on different continents. Condor 100:413-425. https://doi.org/10.2307/1369707

Corona, P., P. Calvani, G. S. Mugnozza, and E. Pompei. 2008. Modelling natural forest expansion on a landscape level by multinomial logistic regression. Plant Biosystems - An International Journal Dealing with all Aspects of Plant Biology 142:509-517. https://doi.org/10.1080/11263500802410850

Croci, S., A. Butet, and P. Clergeau. 2008. Does urbanization filter birds on the basis of their biological traits. Condor 110:223-240. https://doi.org/10.1525/cond.2008.8409

Cumming, G. S., and M. F. Child. 2009. Contrasting spatial patterns of taxonomic and functional richness offer insights into potential loss of ecosystem services. Philosophical Transactions of the Royal Society B: Biological Sciences 364:1683-1692. https:// doi.org/10.1098/rstb.2008.0317

Daw, T., K. Brown, S. Rosendo, and R. Pomeroy. 2011. Applying the ecosystem services concept to poverty alleviation: the need to disaggregate human well-being. Environmental Conservation 38:370-379. https://doi.org/10.1017/S0376892911000506

de Arruda Almeida, B., A. J. Green, E. Sebastián-González, and L. dos Anjos. 2018. Comparing species richness, functional diversity and functional composition of waterbird communities along environmental gradients in the Neotropics. PLoS ONE 13: e0200959. https://doi.org/10.1371/journal.pone.0200959

Díaz, S., S. Demissew, J. Carabias, C. Joly, M. Lonsdale, N. Ash, A. Larigauderie, J. R. Adhikari, S. Arico, A. Báldi, A. Bartuska, I. A. Baste, A. Bilgin, E. Brondizio, K. M. A. Chan, V. E. Figueroa, A. Duraiappah, M. Fischer, R. Hill, T. Koetz, P. Leadley, P. Lyver, G. M. Mace, B. Martin-Lopez, M. Okumura, D. Pacheco, U. Pascual, E. S. Pérez, B. Reyers, E. Roth, O. Saito, R. J. Scholes, N. Sharma, H. Tallis, R. Thaman, R. Watson, T. Yahara, Z. A. Hamid, C. Akosim, Y. Al-Hafedh, R. Allahverdiyev, E. Amankwah, S. T. Asah, Z. Asfaw, G. Bartus, L. A. Brooks, J. Caillaux, G. Dalle, D. Darnaedi, A. Driver, G. Erpul, P. EscobarEyzaguirre, P. Failler, A. M. M. Fouda, B. Fu, H. Gundimeda, S. Hashimoto, F. Homer, S. Lavorel, G. Lichtenstein, W. A. Mala, W. Mandivenyi, P. Matczak, C. Mbizvo, M. Mehrdadi, J. P. Metzger, J. B. Mikissa, H. Moller, H. A. Mooney, P. Mumby, H. Nagendra, C. Nesshover, A. A. Oteng-Yeboah, G. Pataki, M. Roué, J. Rubis, M. Schultz, P. Smith, R. Sumaila, K. Takeuchi, S. Thomas, M. Verma, Y. Yeo-Chang, and D. Zlatanova. 2015. The IPBES conceptual framework - connecting nature and people. Current Opinion in Environmental Sustainability 14:1-16. https:// doi.org/10.1016/j.cosust.2014.11.002
Echeverri, A., D. S. Karp, R. Naidoo, J. A. Tobias, J. Zhao, and K. M. A. Chan. 2020. Can avian functional traits predict cultural ecosystem services? People and Nature 2:138-151. https://doi. org/10.1002/pan3.10058

Elmqvist, T., M. Fragkias, J. Goodness, B. Güneralp, P. J. Marcotullio, R. I. McDonald, S. Parnell, M. Schewenius, M. Sendstad, K. C. Seto, and C. Wilkinson, editors. 2013. Urbanization, biodiversity and ecosystem services: challenges and opportunities a global assessment. Springer, Dordrecht, The Netherlands. https://doi.org/10.1007/978-94-007-7088-1

Etikan, I, S. A. Musa, and R. S. Alkassim. 2016. Comparison of convenience sampling and purposive sampling. American Journal of Theoretical and Applied Statistics 5:1-4. https://doi. org/10.11648/j.ajtas.20160501.11

Fischer, A., and A. Eastwood. 2016. Coproduction of ecosystem services as human-nature interactions - an analytical framework. Land Use Policy 52:41-50. https://doi.org/10.1016/j.landusepol.2015.12.004

Gaston, K. J., M. Soga, J. P. Duffy, J. K. Garrett, S. Gaston, and D. T. C. Cox. 2018. Personalised ecology. Trends in Ecology \& Evolution 33:916-925. https://doi.org/10.1016/j.tree.2018.09.012

Gurney, G. G., J. Blythe, H. Adams, W. N. Adger, M. Curnock, L. Faulkner, T. James, and N. A. Marshall. 2017. Redefining community based on place attachment in a connected world. Proceedings of the National Academy of Sciences of the United States of America 114:10077-10082. https://doi.org/10.1073/ pnas. 1712125114

Gurney, G. G., R. L. Pressey, J. E. Cinner, R. Pollnac, and S. J. Campbell. 2015. Integrated conservation and development: evaluating a community-based marine protected area project for equality of socioeconomic impacts. Philosophical Transactions of the Royal Society of London: Series B, Biological Sciences 370:20140277. https://doi.org/10.1098/rstb.2014.0277

Hamann, M., R. Biggs, and B. Reyers. 2016. An exploration of human well-being bundles as identifiers of ecosystem service use patterns. PLoS ONE 11:e0163476. https://doi.org/10.1371/ journal.pone.0163476

Hicks, C. C., and J. E. Cinner. 2014. Social, institutional, and knowledge mechanisms mediate diverse ecosystem service benefits from coral reefs. Proceedings of the National Academy of Sciences of the United States of America 111:17791-17796. https://doi.org/10.1073/pnas.1413473111

Horcea-Milcu, A.-I., J. Leventon, J. Hanspach, and J. Fischer. 2016. Disaggregated contributions of ecosystem services to human well-being: a case study from Eastern Europe. Regional Environmental Change 16:1779-1791. https://doi.org/10.1007/ s10113-016-0926-2

Iniesta-Arandia, I., M. García-Llorente, P. A. Aguilera, C. Montes, and B. Martín-López. 2014. Socio-cultural valuation of ecosystem services: uncovering the links between values, drivers of change, and human well-being. Ecological Economics 108:36-48. https://doi.org/10.1016/j.ecolecon.2014.09.028

Kahmen, S., P. Poschlod, and K.-F. Schreiber. 2002. Conservation management of calcareous grasslands. Changes in plant species composition and response of functional traits during 25 years. 
Biological Conservation 104:319-328. https://doi.org/10.1016/ S0006-3207(01)00197-5

Kepe, T. 2009. Shaped by race: why "race" still matters in the challenges facing biodiversity conservation in Africa. Local Environment 14:871-878. https://doi.org/10.1080/13549830903164185

Kittinger, J. N., T. M. Bambico, T. K. Watson, and E. W. Glazier. 2012. Sociocultural significance of the endangered Hawaiian monk seal and the human dimensions of conservation planning. Endangered Species Research 17:139-156. https://doi.org/10.3354/ $\underline{\text { esr00423 }}$

Koster, J., and R. McElreath. 2017. Multinomial analysis of behavior: statistical methods. Behavioral Ecology and Sociobiology 71:138. https://doi.org/10.1007/s00265-017-2363-8

Lapointe, M., G. S. Cumming, and G. G. Gurney. 2019. Comparing ecosystem service preferences between urban and rural dwellers. BioScience 69:108-116. https://doi.org/10.1093/ $\underline{\text { biosci/biy } 151}$

Lapointe, M., G. G. Gurney, and G. S. Cumming. 2020. Urbanization alters ecosystem service preferences in a small island developing state. Ecosystem Services 43:101109. https:// doi.org/10.1016/j.ecoser.2020.101109

Lau, J. D., C. C. Hicks, G. G. Gurney, and J. E. Cinner. 2018. Disaggregating ecosystem service values and priorities by wealth, age, and education. Ecosystem Services 29:91-98. https://doi. org/10.1016/j.ecoser.2017.12.005

Lau, J. D., C. C. Hicks, G. G. Gurney, and J. E. Cinner. 2019. What matters to whom and why? Understanding the importance of coastal ecosystem services in developing coastal communities. Ecosystem Services 35:219-230. https://doi.org/10.1016/j. ecoser.2018.12.012

Lindemann-Matthies, P., D. Keller, X. Li, and B. Schmid. 2014. Attitudes toward forest diversity and forest ecosystem servicesa cross-cultural comparison between China and Switzerland. Journal of Plant Ecology 7:1-9. https://doi.org/10.1093/jpe/rtt015

Martin, A., B. Coolsaet, E. Corbera, N. M. Dawson, J. A. Fraser, I. Lehmann, and I. Rodriguez. 2016. Justice and conservation: the need to incorporate recognition. Biological Conservation 197:254-261. https://doi.org/10.1016/j.biocon.2016.03.021

Mensah, S., R. Veldtman, A. E. Assogbadjo, C. Ham, R. Glèlè Kakaï, and T. Seifert. 2017. Ecosystem service importance and use vary with socio-environmental factors: a study from household-surveys in local communities of South Africa. Ecosystem Services 23:1-8. https://doi.org/10.1016/j.ecoser.2016.10.018

Millennium Ecosystem Assessment (MA). 2005. Ecosystems and human well-being: synthesis. Island, Washington, D.C., USA.

Musavengane, R., and L. Leonard. 2019. When race and social equity matters in nature conservation in post-apartheid South Africa. Conservation \& Society 17:135-146.

Nengwekhulu, R. H. 1986. Race, class and ethnicity in South Africa. African Journal of Political Economy/Revue Africaine d'Economie Politique 1:29-39.
Plieninger, T., S. Dijks, E. Oteros-Rozas, and C. Bieling. 2013. Assessing, mapping, and quantifying cultural ecosystem services at community level. Land Use Policy 33:118-129. https://doi. org/10.1016/j.landusepol.2012.12.013

Ramutsindela, M. 2007. Resilient geographies: land, boundaries and the consolidation of the former Bantustans in post-1994 South Africa. Geographical Journal 173:43-55. https://doi. org/10.1111/j.1475-4959.2007.00230.x

Scholte, S. S. K., A. J. A. van Teeffelen, and P. H. Verburg. 2015. Integrating socio-cultural perspectives into ecosystem service valuation: a review of concepts and methods. Ecological Economics 114:67-78. https://doi.org/10.1016/j.ecolecon.2015.03.007

Sekercioglu, C. H. 2002. Impacts of birdwatching on human and avian communities. Environmental Conservation 29:282-289. https://doi.org/10.1017/S0376892902000206

Sievers-Glotzbach, S. 2013. Ecosystem services and distributive justice: considering access rights to ecosystem services in theories of distributive justice. Ethics, Policy \& Environment 16:162-176. https://doi.org/10.1080/21550085.2013.801203

Sikor, T. 2013. The justices and injustices of ecosystem services. Routledge, London, UK. https://doi.org/10.4324/9780203395288

Smit, W. 1998. The rural linkages of urban households in Durban, South Africa. Environment and Urbanization 10:77-88. https:// doi.org/10.1177/095624789801000119

Statistics South Africa. 2011. Census 2011. Statistics South Africa, Pretoria, South Africa.

Suri, J., P. M. Anderson, T. Charles-Dominique, E. Hellard, and G. S. Cumming. 2017. More than just a corridor: a suburban river catchment enhances bird functional diversity. Landscape and Urban Planning 157:331-342. https://doi.org/10.1016/j.

landurbplan.2016.07.013

Taylor, M. R., and F. Peacock. 2018. The state of South Africa's bird report 2018. BirdLife South Africa, Johannesburg, South Africa.

Tengberg, A., S. Fredholm, I. Eliasson, I. Knez, K. Saltzman, and O. Wetterberg. 2012. Cultural ecosystem services provided by landscapes: assessment of heritage values and identity. Ecosystem Services 2:14-26. https://doi.org/10.1016/j.ecoser.2012.07.006

Upton, G. J. G. 2017. Multinomial logistic regression. Pages 109-124 in Categorical data analysis by example. John Wiley \& Sons, Inc, Hoboken, New Jersey, USA. https://doi. org/10.1002/9781119450382.ch10

Yang, Y., H. Zheng, L. Kong, B. Huang, W. Xu, and Z. Ouyang. 2019. Mapping ecosystem services bundles to detect high- and low-value ecosystem services areas for land use management. Journal of Cleaner Production 225:11-17. https://doi. org/10.1016/j.jclepro.2019.03.242

Zoderer, B. M., P. S. Lupo Stanghellini, E. Tasser, J. Walde, H. Wieser, and U. Tappeiner. 2016. Exploring socio-cultural values of ecosystem service categories in the Central Alps: the influence of socio-demographic factors and landscape type. Regional 
Ecology and Society 26(3): 20 https://www.ecologyandsociety.org/vol26/iss3/art20/

Environmental Change 16:2033-2044. https://doi.org/10.1007/ s10113-015-0922-y

Zoeller, K. C., G. G. Gurney, J. Heydinger, and G. S. Cumming. 2020. Defining cultural functional groups based on perceived traits assigned to birds. Ecosystem Services 44:101138. https:// doi.org/10.1016/j.ecoser.2020.101138 
Appendix 1. Respondent characteristics and their percentage contribution to the sample.

Respondent characteristics

$\%$ (and number of) respondents

\section{Birding self-classification}

Non-birder

$$
\begin{array}{r}
36(n=146) \\
45(n=184) \\
15(n=62) \\
2(n=9)
\end{array}
$$

Casual birder

Enthusiastic birder

Fanatical birder

\section{Frequency of bird encounters}

Daily

$83(n=333)$

Once a week

$11(n=46)$

Once a month

$5(\mathrm{n}=18)$

Once a year

$$
1(\mathrm{n}=4)
$$

\section{Ethnicity}

Black

$32(n=128)$

Coloured

$26(n=108)$

White

$39(n=160)$

\section{Languages}

Afrikaans

$38(n=153)$

English

$31(n=126)$

Xhosa

$19(\mathrm{n}=76)$

Other African languages

$11(n=46)$

Sex

Male

$47(n=187)$

Female

$53(n=214)$

\section{Highest educational qualification}

Grade 9 or lower

$14(\mathrm{n}=57)$

Grade 10 to Grade 12

$48(n=196)$

University or technical college graduates

$30(n=121)$

Masters graduates

$5(\mathrm{n}=17)$

$\mathrm{PhD}$ graduates

$3(\mathrm{n}=10)$ 
Appendix 2. Description of dominant traits that characterise cultural functional groups.

Cultural functional group name

Visual Traits

Dominant traits

Colourful/handsome plumage

Positive response to the bird's name

Small body

Stance

Shape

Negative Visual and Negative Behavioural Traits

Dull/ugly plumage
Negative song

Negative habitat

Difficult to identify

Aversion for the bird at the family level

Invasive/pest

Negative symbology

Boring/average behaviour

Aggressive/territorial

Movement and Ecological Traits

Interesting foraging behaviour

Conspicuous

Affinity for the bird at the family level

Camouflage/adaptability

Clever

Endangered

Strong/powerful

Place Association and Abundance Indicators

Positive song

Positive habitat

Rare

Migratory

Few sightings of the species

Breeding display

Difficult to locate

Indigenous/endemic

Positive association with their sighting

Positive symbology

Easy to identify

Common

Common Traits

Many sightings of the species

Confiding

Behavioural Traits

Large body

Interesting movement

Parental care

Flock size

Source of food 
Appendix 3. Frequency of species occurrence in each cultural functional group.

Acacia Pied Barbet

African Barred Owlet

African Black Crake

African Black Duck

African Black Oystercatcher

African Black Swift

African Cuckoo

African Darter

African Dusky Flycatcher

African Firefinch

African Fish Eagle

African Goshawk

African Green Pigeon

African Grey Hornbill

African Harrier-hawk

African Hawk-Eagle

African Hoopoe

African Jacana

African Marsh Harrier

African Olive Pigeon

African Openbill

African Palm Swift

African Paradise Flycatcher

African Pied Wagtail

African Pipit

African Quailfinch

African Reed Warbler

African Rock Pipit

African Sacred Ibis

African Snipe

African Spoonbill

Traits

$\begin{array}{lll} & \text { Negative } & \text { Movement } \\ & \text { Visual } & \text { and } \\ \text { Visual } & \text { and } & \text { Ecological } \\ \text { Traits } & \text { Traits } & \text { Traits }\end{array}$

Place

Association

and

Abundance Behavioural Common

Indicators Traits

Traits

219

8

63

6

10

58

4

5

7

$9 \quad 11$

113

5

228

$4 \quad 9$

17

9

5

27

5

9

7

12

11

13

3

10

21

2

5

15

2

14

33

11

7

13

7

$9 \quad 6$

13

1

1

5

1

3

3

7

(7)

2

2

1

3

1

African Stonechat

African Swamphen

Agulhas Long-billed Lark

4

21

Alpine Swift

Amethyst Sunbird

Amur Falcon

Ant-eating Chat

Arrow-marked Babbler

Ashy Flycatcher 


\begin{tabular}{|c|c|c|c|c|c|}
\hline Ashy Tit & 1 & 8 & 10 & & 2 \\
\hline Banded Martin & & 8 & 8 & & 4 \\
\hline Bank Cormorant & 7 & 6 & 2 & & 3 \\
\hline Barlow's Lark & 1 & 10 & 18 & 2 & 1 \\
\hline Barn Owl & 3 & 16 & 5 & 2 & 12 \\
\hline Barn Swallow & 1 & 7 & 12 & 6 & 3 \\
\hline Barratt's Warbler & 7 & 23 & 13 & 1 & 1 \\
\hline Barred Wren-Warbler & 1 & 10 & 6 & 1 & \\
\hline Bar-throated Apalis & & & 1 & & \\
\hline Bateleur & 3 & 3 & 13 & & 11 \\
\hline Bearded Vulture & & 16 & 5 & 1 & 6 \\
\hline Bearded Woodpecker & 5 & 8 & 13 & 1 & 1 \\
\hline Bennett's Woodpecker & 6 & 5 & 3 & & \\
\hline Black Cuckoo & & 8 & 8 & 2 & \\
\hline Black Cuckooshrike & 2 & 8 & 17 & & \\
\hline Black Harrier & 1 & 4 & 5 & 2 & 20 \\
\hline Black Saw-wing & 1 & 17 & 4 & & \\
\hline Black-backed Puffback & 1 & 2 & 18 & & \\
\hline Black-bellied Bustard & 4 & 6 & 8 & & \\
\hline Black-bellied Starling & 1 & 5 & 14 & 1 & 1 \\
\hline Black-chested Prinia & 4 & 13 & 5 & 3 & 1 \\
\hline Black-chested Snake-Eagle & & & 3 & & 2 \\
\hline Black-collared Barbet & 4 & 2 & 10 & 2 & 1 \\
\hline Black-crowned Tchagra & 3 & 4 & 18 & & 2 \\
\hline Black-eared Sparrowlark & 3 & 16 & 11 & 2 & 1 \\
\hline Black-faced waxbill & 3 & 2 & 20 & & 1 \\
\hline Black-headed Canary & & 4 & 13 & 3 & 2 \\
\hline Black-headed Heron & 2 & 1 & 2 & 1 & 6 \\
\hline Black-headed Oriole & 4 & & 10 & 1 & \\
\hline Black-necked Grebe & 7 & 9 & 1 & & 1 \\
\hline Black-shouldered Kite & 2 & 5 & 4 & 1 & 11 \\
\hline Blacksmith Lapwing & 7 & 3 & 7 & 2 & \\
\hline Black-throated Canary & 3 & 12 & 11 & & \\
\hline Black-winged Lapwing & 2 & 5 & 5 & 5 & 2 \\
\hline Black-winged Stilt & 2 & 2 & 1 & & 4 \\
\hline Blue Crane & 2 & 5 & 11 & 1 & \\
\hline Blue Korhaan & 5 & 6 & 8 & & \\
\hline Blue Waxbill & 4 & 1 & 14 & 1 & \\
\hline Blue-mantled Crested & & & & & \\
\hline Flycatcher & 3 & 3 & 9 & 1 & 3 \\
\hline Bokmakierie & 2 & 2 & 3 & & \\
\hline Booted Eagle & & 7 & 2 & & 14 \\
\hline Bradfield's Swift & 1 & 16 & 2 & & \\
\hline Brimstone Canary & 4 & 9 & 18 & 3 & 3 \\
\hline Broad-billed Roller & 1 & 3 & 15 & & 1 \\
\hline Bronze Mannikin & 3 & 8 & 23 & 1 & \\
\hline
\end{tabular}


Brown Scrub-Robin

Brown-crowned Tchagra

Brown-headed Parrot

Brown-hooded Kingfisher

Brown-throated Martin

Brubru

Buff-spotted Flufftail

Buff-streaked Chat

Buffy Pipit

Burchell's Coucal

Burchell's Sandgrouse

Burchell's Starling

Burnt-necked Eremomela

Bushveld Pipit

Cape Batis

Cape Bunting

Cape Canary

Cape Clapper Lark

Cape Cormorant

Cape Crow

Cape Gannet

Cape Glossy Starling

Cape Grassbird

Cape Long-billed Lark

Cape Longclaw

Cape Penduline Tit

Cape Rock Thrush

3

Cape Shoveler

Cape Siskin

Cape Sparrow

Cape Spurfowl

Cape Sugarbird

Cape Teal

Cape Vulture

Cape Wagtail

Cape Weaver

Cape White-eye

Capped Wheatear

Cardinal Woodpecker

Cattle Egret

Chat Flycatcher

Chestnut-banded Plover

Chestnut-vented Tit-Babbler 


\begin{tabular}{|c|c|c|c|c|c|c|}
\hline Cinnamon-breasted Bunting & 1 & 1 & 6 & 1 & & \\
\hline Cloud Cisticola & 4 & 4 & 14 & & 1 & 2 \\
\hline Collared Pratincole & 4 & 6 & 8 & 1 & 1 & 2 \\
\hline Collared Sunbird & 7 & & 4 & & 6 & 4 \\
\hline Common Buzzard & 2 & 4 & 2 & 2 & 8 & 2 \\
\hline Common Cuckoo & 4 & 9 & 11 & & 1 & \\
\hline Common Greenshank & 6 & 2 & 5 & & 5 & 7 \\
\hline Common House Martin & & 4 & 5 & 3 & 1 & 1 \\
\hline Common Moorhen & 8 & 5 & 3 & 6 & 1 & 4 \\
\hline Common Myna & & 9 & 15 & 2 & & \\
\hline Common Ostrich & 5 & 4 & 3 & 5 & & 12 \\
\hline Common Quail & 6 & 18 & 15 & 7 & 2 & 13 \\
\hline Common Ringed Plover & 3 & 2 & 6 & 1 & & 8 \\
\hline Common Sandpiper & 6 & 5 & 3 & 2 & 4 & 2 \\
\hline Common Scimitarbill & 2 & 6 & 5 & & 7 & \\
\hline Common Starling & 1 & 14 & 11 & 11 & 2 & \\
\hline Common Swift & 2 & 6 & 2 & 5 & 3 & 1 \\
\hline Common Tern & 8 & 4 & 5 & 3 & 1 & 1 \\
\hline Common Waxbill & 1 & 1 & 14 & 1 & 2 & 1 \\
\hline Coqui Francolin & 7 & 15 & 8 & 2 & & 8 \\
\hline Crested Barbet & 4 & 5 & 24 & 2 & 1 & 1 \\
\hline Crested Francolin & 4 & 3 & 1 & 5 & & 7 \\
\hline Crested Guineafowl & 2 & 5 & 5 & 8 & 1 & 7 \\
\hline Crimson-breasted Shrike & 8 & 4 & 14 & & 2 & \\
\hline Crowned Cormorant & 5 & 8 & 4 & & & 3 \\
\hline Crowned Hornbill & 2 & 5 & 7 & 2 & 3 & \\
\hline Crowned Lapwing & 3 & 4 & 8 & 1 & & 12 \\
\hline Curlew Sandpiper & 10 & 3 & 1 & 1 & 2 & 2 \\
\hline Cut-throat Finch & 3 & 5 & 21 & & 2 & 1 \\
\hline Dark Chanting Goshawk & 1 & 4 & 5 & 1 & 8 & 1 \\
\hline Dark-backed Weaver & 3 & 3 & 10 & & & 1 \\
\hline Dark-capped Bulbul & 3 & 5 & 15 & 7 & & 1 \\
\hline Denham's Bustard & 6 & 6 & 2 & & & 5 \\
\hline Desert Cisticola & 6 & 3 & 9 & & 2 & \\
\hline Dickinson's Kestrel & 2 & 5 & 4 & & 11 & \\
\hline Diederik Cuckoo & 4 & 3 & 11 & & 1 & 2 \\
\hline Double-banded Courser & 7 & 4 & 11 & 1 & 1 & 7 \\
\hline Double-banded Sandgrouse & 1 & 9 & 4 & & & 6 \\
\hline Drakensberg Prinia & 2 & 10 & 6 & 1 & & 1 \\
\hline Dusky Indigobird & & 2 & 14 & 1 & 2 & 1 \\
\hline Dusky Lark & & 4 & 11 & 1 & 1 & 3 \\
\hline Dusky Sunbird & 6 & 4 & 3 & 1 & 7 & \\
\hline Eastern Clapper Lark & 3 & 8 & 13 & & & \\
\hline Eastern Long-billed Lark & 1 & 10 & 9 & 1 & & 1 \\
\hline Eastern Nicator & 3 & 13 & 24 & & & \\
\hline Emerald-spotted Wood Dove & 8 & 7 & 24 & 3 & 2 & 3 \\
\hline
\end{tabular}




\begin{tabular}{|c|c|c|c|c|c|c|}
\hline Eurasian Golden Oriole & 3 & 9 & 8 & & & \\
\hline European Bee-eater & 2 & 2 & 13 & & 5 & 1 \\
\hline European Honey Buzzard & 1 & 6 & 11 & & 9 & 1 \\
\hline European Roller & 4 & 2 & 34 & & 1 & 2 \\
\hline Fairy Flycatcher & 3 & 2 & 10 & 2 & 4 & 1 \\
\hline Familiar Chat & 2 & 9 & 11 & & 1 & $\varepsilon$ \\
\hline Fawn-coloured Lark & 1 & 14 & 9 & & & 3 \\
\hline Fiery-necked Nightjar & 3 & 10 & 7 & & 1 & 1 \\
\hline Fiscal Flycatcher & & 1 & 1 & & 1 & 1 \\
\hline Flappet Lark & 4 & 18 & 6 & 6 & & 2 \\
\hline Forest Buzzard & 1 & 10 & 7 & 1 & 12 & \\
\hline Forest Canary & 14 & 2 & 16 & 6 & 2 & 1 \\
\hline Fork-tailed Drongo & 3 & 10 & 4 & 2 & 1 & \\
\hline Gabar Goshawk & 1 & 13 & 8 & & 14 & \\
\hline Giant Kingfisher & 1 & 6 & 5 & & 15 & 1 \\
\hline Golden-breasted Bunting & 5 & 2 & 29 & 1 & 2 & 3 \\
\hline Golden-tailed Woodpecker & 6 & 7 & 16 & & 3 & 11 \\
\hline Goliath Heron & 7 & 12 & 4 & & 4 & s \\
\hline Gorgeous Bushshrike & 5 & 5 & 37 & 1 & 3 & 2 \\
\hline Great Egret & 6 & 7 & 4 & 3 & 7 & 6 \\
\hline Great Reed Warbler & 1 & 10 & 13 & 2 & & 1 \\
\hline Great Sparrow & 2 & 2 & 15 & 5 & 1 & 1 \\
\hline Great Spotted Cuckoo & 3 & 4 & 12 & & 1 & 2 \\
\hline $\begin{array}{l}\text { Greater Blue-eared Starling } \\
\text { Greater Double-collared }\end{array}$ & 1 & 3 & 15 & 2 & 1 & \\
\hline Sunbird & 12 & & 6 & & 4 & \\
\hline Greater Flamingo & 5 & 3 & 3 & & 2 & \\
\hline Greater Honeyguide & 3 & 10 & 5 & & 2 & 1 \\
\hline Greater Kestrel & & 3 & 3 & & 10 & \\
\hline Greater Striped Swallow & 2 & 2 & 12 & 3 & 1 & \\
\hline Green Wood Hoopoe & 5 & & 17 & & 1 & 3 \\
\hline Green-backed Camaroptera & 3 & 5 & 9 & & 2 & 1 \\
\hline Green-backed Heron & 6 & 8 & 4 & & 4 & 3 \\
\hline Green-capped Eremomela & 2 & 10 & 18 & & 1 & \\
\hline Green-winged Pytilia & 2 & 2 & 18 & & 1 & 1 \\
\hline Grey Cuckooshrike & 3 & 10 & 11 & & & 1 \\
\hline Grey Go-away Bird & 6 & 5 & 8 & 3 & & \\
\hline Grey Heron & 12 & 6 & 3 & 1 & 11 & 6 \\
\hline Grey Penduline Tit & 13 & 1 & 7 & 1 & 2 & 1 \\
\hline Grey Plover & 6 & 1 & 4 & 1 & 1 & 7 \\
\hline Grey Sunbird & 1 & 5 & 5 & 2 & 12 & 1 \\
\hline Grey Tit & 5 & 9 & 23 & 5 & 6 & 2 \\
\hline Grey Tit Flycatcher & 2 & 4 & 12 & 1 & 4 & 1 \\
\hline Grey-backed Camaroptera & 2 & 7 & 7 & & & \\
\hline Grey-backed Cisticola & 8 & 4 & 11 & 3 & 2 & \\
\hline Grey-backed sparrowlark & 2 & 4 & 9 & 2 & 5 & \\
\hline
\end{tabular}


Grey-headed Bushshrike

Grey-headed Gull

12

Grey-headed Kingfisher

Grey-headed Parrot

Grey-rumped Swallow

Grey-winged Francolin

Ground Woodpecker

Groundscraper Thrush

Gurney's Sugarbird

Hadeda Ibis

Half-collared Kingfisher

Hamerkop

Hartlaub's Gull

Helmeted Guineafowl

Hooded Vulture

Horus Swift

House Sparrow

Jackal Buzzard

Jacobin Cuckoo

Jameson's Firefinch

Kalahari Scrub-Robin

Karoo Chat

Karoo Eremomela

Karoo Korhaan

Karoo Lark

Karoo Long-billed Lark

Karoo Prinia

Karoo Scrub-Robin

Karoo Thrush

Kelp Gull

Kittlitz's Plover

Klaas's Cuckoo

Knob-billed Duck

Knysna Turaco

Knysna Warbler

Knysna Woodpecker

Kori Bustard

Kurrichane Thrush

Lanner Falcon

Lappet-faced Vulture

Large-billed Lark

Lark-like Bunting

Laughing Dove

Layard's Tit-Babbler

Lazy Cisticola

Lemon Dove

2

7

2

4

4

3

16

14

6

6

9

1

1

10

4

3

5

6

6

5

3

2

3

10

4

3

1

6

6

7

3

2

9

5

6

5

1

1

18

7

$$
4
$$$$
7
$$

14

12

$$
4
$$$$
6
$$$$
11
$$$$
2
$$$$
3
$$$$
3
$$$$
6
$$$$
2
$$$$
1
$$$$
4
$$$$
4
$$$$
1
$$$$
5
$$$$
8
$$$$
15
$$$$
8
$$$$
9
$$$$
12
$$$$
1
$$$$
9
$$$$
7
$$$$
10
$$$$
16
$$$$
9
$$$$
8
$$$$
1
$$$$
27
$$$$
8
$$$$
4
$$$$
10
$$$$
3
$$$$
9
$$$$
10
$$$$
\begin{aligned}
& 1 \\
& 3
\end{aligned}
$$$$
16
$$$$
10
$$$$
2
$$$$
10
$$$$
16
$$$$
9
$$

$\begin{array}{rr}15 & 16 \\ 7 & 9\end{array}$

\section{1}




\begin{tabular}{|c|c|c|c|c|c|c|}
\hline Lesser Flamingo & 10 & 3 & 6 & & 3 & 3 \\
\hline Lesser Grey Shrike & 2 & 3 & 10 & & 9 & \\
\hline Lesser Honeyguide & 5 & 8 & 12 & & 1 & \\
\hline Lesser Kestrel & 4 & 6 & 9 & 1 & 12 & 3 \\
\hline Lesser Masked Weaver & 5 & 3 & 9 & 8 & & \\
\hline Lesser Spotted Eagle & 1 & 8 & 9 & & 8 & 2 \\
\hline Lesser Striped Swallow & 3 & 3 & 7 & 3 & 1 & \\
\hline Lesser Swamp Warbler & 3 & 15 & 1 & 4 & & 2 \\
\hline Levaillant's Cisticola & 2 & 12 & 9 & & & \\
\hline Levaillant's Cuckoo & 1 & 8 & 11 & & & \\
\hline Lilac-breasted Roller & 6 & & 19 & 2 & & 1 \\
\hline Little Bee-eater & 6 & & 13 & 1 & 4 & 2 \\
\hline Little Egret & 7 & & 1 & 3 & 1 & \\
\hline Little Grebe & 8 & 2 & 2 & & & 9 \\
\hline Little Sparrowhawk & 1 & 4 & 2 & & 6 & \\
\hline Little Stint & 9 & & 4 & & & 6 \\
\hline Little Swift & 1 & 7 & 6 & 1 & 3 & 1 \\
\hline Lizard Buzzard & 1 & 9 & 16 & & 11 & 2 \\
\hline Long-billed Crombec & 1 & 8 & 11 & & 1 & 2 \\
\hline Long-billed Pipit & 1 & 7 & 22 & & 2 & \\
\hline Long-crested Eagle & 1 & 9 & 3 & & 16 & \\
\hline Long-tailed Paradise Whydah & 2 & 3 & 14 & & & 3 \\
\hline Long-tailed Widowbird & 3 & 7 & 11 & & & \\
\hline Ludwig's Bustard & 8 & 5 & 4 & & 1 & 4 \\
\hline Magpie Shrike & 1 & 7 & 13 & & 4 & 3 \\
\hline Malachite Kingfisher & 2 & & 9 & 1 & 12 & 2 \\
\hline Malachite Sunbird & 18 & 2 & 4 & 2 & 8 & 2 \\
\hline Marabou Stork & 1 & 14 & 1 & 1 & 2 & 1 \\
\hline Marico Flycatcher & 2 & 6 & 20 & 2 & 2 & 1 \\
\hline Marico Sunbird & 5 & & 11 & 2 & 3 & 1 \\
\hline Marsh Sandpiper & 13 & 8 & 2 & 1 & 1 & 12 \\
\hline Martial Eagle & & 2 & 2 & & 4 & \\
\hline Meves's Starling & 4 & 4 & 14 & 3 & & \\
\hline Meyer's Parrot & 4 & 12 & 22 & & 1 & 3 \\
\hline Mocking Cliff-Chat & 4 & 3 & 16 & & 1 & 1 \\
\hline Monotonous Lark & 3 & 14 & 5 & 2 & & \\
\hline Mosque Swallow & 2 & 9 & 12 & & 3 & \\
\hline Mountain Wheatear & 3 & 6 & 13 & 1 & 2 & \\
\hline Namaqua Dove & 8 & 5 & 3 & 2 & & 2 \\
\hline Namaqua Sandgrouse & 2 & 3 & 7 & & & 4 \\
\hline Namaqua Warbler & 3 & 7 & 8 & 1 & 1 & \\
\hline Narina Trogon & 10 & 2 & 25 & & 1 & 2 \\
\hline Natal Spurfowl & 2 & 3 & 3 & 3 & & 9 \\
\hline Neddicky & 5 & 11 & 6 & 7 & & 1 \\
\hline Northern Black Korhaan & 7 & 6 & 16 & & 2 & 4 \\
\hline Olive Bushshrike & 5 & 1 & 20 & 1 & 6 & 1 \\
\hline
\end{tabular}


Olive Thrush

Olive Woodpecker

Orange River White-eye

Orange-breasted Bushshrike

Orange-breasted Sunbird

Pacific Golden Plover

Pale Chanting Goshawk

Pale Flycatcher

Pale-winged Starling

Pearl-breasted Swallow

Pearl-spotted Owlet

Peregrine Falcon

Pied Crow

Pied Kingfisher

Pied Starling

Pink-billed Lark

Pin-tailed Whydah

Plain-backed Pipit

Pririt Batis

Purple Heron

Purple Roller

Purple-crested Turaco

Pygmy Falcon

Pygmy Kingfisher

Rattling Cisticola

Red-backed Shrike

Red-billed Buffalo-weaver

Red-billed Firefinch

Red-billed Oxpecker

Red-billed Quelea

Red-billed Teal

Red-breasted Swallow

Red-capped Lark

Red-capped Robin-Chat

Red-chested Cuckoo

Red-collared Widowbird

Red-crested Korhaan

Red-eyed Dove

Red-faced Cisticola

Red-faced Mousebird

Red-fronted Tinkerbird

Red-headed Finch

Red-headed Weaver

Red-knobbed Coot

Red-necked Spurfowl

Red-throated Wryneck 


\begin{tabular}{|c|c|c|c|c|c|c|}
\hline Red-winged Starling & 1 & 4 & 9 & 8 & & 1 \\
\hline Reed Cormorant & 4 & 8 & & 1 & 1 & 3 \\
\hline Reitz's Helmetshrike & & 3 & 18 & & 4 & \\
\hline Rock Dove & 4 & 5 & 2 & 7 & & 2 \\
\hline Rock Kestrel & 2 & 4 & 2 & & 4 & 2 \\
\hline Rock Martin & 3 & 9 & 8 & 2 & & 1 \\
\hline Ruddy Turnstone & 7 & 3 & 7 & & 2 & 1 \\
\hline Ruff & 7 & 6 & 4 & 1 & & 3 \\
\hline Rufous-cheeked Nightjar & 4 & 9 & 6 & & 1 & \\
\hline Rufous-eared Warbler & 6 & 1 & 7 & 1 & 3 & \\
\hline Rufous-naped Lark & 1 & 13 & 8 & & 1 & \\
\hline Rufous-winged Cisticola & 2 & 4 & 12 & 2 & & \\
\hline Sabota Lark & 6 & 15 & 15 & 3 & 1 & \\
\hline Saddle-billed Stork & 12 & 3 & 3 & & 3 & 3 \\
\hline Sandwich Tern & 14 & 9 & 7 & & 2 & \\
\hline Scaly-feathered Finch & 2 & 3 & 6 & & 2 & 2 \\
\hline Scaly-throated Honeyguide & 8 & 9 & 6 & 1 & 1 & 1 \\
\hline Scarlet-chested Sunbird & 4 & 3 & 5 & & 7 & 2 \\
\hline Secretarybird & 4 & 4 & 5 & & 5 & 4 \\
\hline Senegal Lapwing & & 6 & 11 & & & 10 \\
\hline Sentinel Rock Thrush & & 1 & 15 & 2 & & 4 \\
\hline Shaft-tailed Whydah & 1 & 3 & 14 & & & 1 \\
\hline Shelley's Francolin & 2 & 7 & 3 & 1 & & 8 \\
\hline Shelley's Sunbird & 6 & & 6 & & 12 & 1 \\
\hline Shikra & 3 & 5 & 6 & & 8 & 2 \\
\hline Short-toed Rock-Thrush & 2 & 3 & 9 & & 2 & 1 \\
\hline Sickle-winged Chat & 2 & 4 & 7 & & & \\
\hline Sociable Weaver & 3 & 10 & 16 & 1 & & 1 \\
\hline Sombre Greenbul & 2 & 14 & 11 & 3 & & \\
\hline South African Cliff Swallow & 11 & 5 & 9 & 1 & & 1 \\
\hline South African Shelduck & 3 & 4 & 3 & & 1 & 9 \\
\hline Southern Black Flycatcher & 1 & 9 & 5 & 1 & 4 & 1 \\
\hline Southern Black Korhaan & 3 & 1 & 5 & & 1 & 7 \\
\hline Southern Black Tit & 2 & 7 & 10 & 1 & & \\
\hline Southern Boubou & 5 & 4 & 3 & 1 & 2 & 2 \\
\hline $\begin{array}{l}\text { Southern Carmine Bee-Eater } \\
\text { Southern Double-collared }\end{array}$ & 1 & & 17 & & 4 & \\
\hline Sunbird & 9 & 1 & 5 & 1 & 11 & 3 \\
\hline $\begin{array}{l}\text { Southern Fiscal } \\
\text { Southern Grey-headed }\end{array}$ & & 3 & 3 & 2 & & \\
\hline Sparrow & 4 & 9 & 13 & 12 & 2 & \\
\hline Southern Ground Hornbill & 7 & 7 & 3 & & 1 & 2 \\
\hline Southern Masked Weaver & 2 & 1 & 4 & 3 & & 2 \\
\hline Southern Pied Babbler & 7 & 2 & 9 & 2 & 1 & 1 \\
\hline Southern Red Bishop & 2 & 1 & 6 & 3 & & 1 \\
\hline Southern Red-billed Hornbill & 7 & 6 & 10 & 1 & & 1 \\
\hline Southern Tchagra & 1 & 6 & 12 & 1 & & \\
\hline
\end{tabular}


Southern White-crowned

Shrike

Southern Yellow-billed

Hornbill

Speckled Mousebird

Speckled Pigeon

Spectacled Weaver

Spike-heeled Lark

Spotted Eagle-Owl

Spotted Flycatcher

Spotted Thick-knee

Spur-winged Goose

Squacco Heron

Stark's Lark

Stierling's Wren-Warbler

Streaky-headed Seedeater

Striped Kingfisher

Striped Pipit

Swainson's Spurfowl

Swallow-tailed Bee-eater

Swee Waxbill

Swift Tern

Tambourine Dove

Tawny Eagle

Tawny-flanked Prinia

Temminck's Courser

Terrestrial Brownbul

Thick-billed Weaver

Three-banded Plover

Tractrac Chat

Tropical Boubou

Trumpeter Hornbill

Verreaux's Eagle

Verreaux's Eagle-Owl

Victorin's Warbler

Village Indigobird

Violet-backed Starling

Violet-eared Waxbill

Wahlberg's Eagle

Wailing Cisticola

Water Thick-knee

Wattled Starling

Whiskered Tern

White Stork

White-backed Duck

White-backed Mousebird

White-backed Vulture 
White-bellied Sunbird

$3 \quad 2 \quad 3$

White-breasted Cormorant

362

White-browed Robin-Chat

$4 \quad 3$

White-browed Scrub-robin

$2 \quad 10$

7

White-browed Sparrow

Weaver

White-crested Helmetshrike

White-faced Whistling Duck

White-fronted Bee-eater

White-fronted Plover

White-necked Raven

White-rumped Swift

White-throated Canary

White-throated Robin-Chat

White-throated Swallow

White-winged Tern

White-winged Widowbird

Willow Warbler

Wing-snapping Cisticola

Wire-tailed Swallow

Wood Sandpiper

Woodland Kingfisher

Yellow Bishop

Yellow Canary

Yellow-bellied Eremomela

Yellow-bellied Greenbul

Yellow-billed Duck

Yellow-billed Kite

Yellow-billed Oxpecker

Yellow-billed Stork

Yellow-breasted Apalis

Yellow-crowned Bishop

Yellow-fronted Canary

Yellow-fronted Tinkerbird

Yellow-throated Longclaw

Yellow-throated Petronia

Yellow-throated Woodland

Warbler

Zitting Cisticola 